\title{
NATIVE SPEAKER IN TEACHING ENGLISH TO INDONESIAN STUDENTS AT ICP FMIPA UNM
}

\author{
Nurfajrih Ningsih \\ Institut Parahiklam Indonesia \\ nurfajrih@gmail.com
}

\begin{abstract}
The aim of this paper is to find out the method applied by the native speaker in teaching English to Indonesian students at ICP FMIPA UNM. This research was case study. The subject of the research is a native spekear who teach at ICP FMIPA UNM. The result of the research shows that The procedures of teaching applied by native speaker in teaching English to Indonesian students at ICP UNM are the procedure required by direct method, ausdion lingual mehod, and communicative language teaching. Besides, the lecturer varied activities in each meeting through some kind of activities. The lecturer also always applied two main activities in each meeting.
\end{abstract}

KEYWORDS: Native Speaker lecturer, Indonesian students

\section{INTRODUCTION}

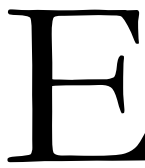

nglish is one of the most important subjects in many countries where English used as a foreign language, such as China, Japan, France, Germany, Mexico,

Israel, Indonesia (Wello,1999:2). Nowadays, many countries have introduced

English classes to elementary schools, and many adults study English even after graduating from universities.

In spite of this enthusiasm for studying English, the profile of English language teaching and learning process in Indonesia is not well researched, although teaching and learning strategies could definitely help the teacher more efficiently if they knew and employed such strategies consciously.

On the other side the profile of Indonesian students' strategies for learning English is not well researched too, which is similar to that of English learners' strategies in the context of English as a foreign language (EFL). Likewise, "learning strategy" is still quite a vague concept to Indonesian EFL learners.

In teaching English as a foreign language, there are many factors that can influence students in learning English. In this case, there are elements to make the process of teaching and learning possible in the classroom such as teacher, student, materials, time and place. All of them are related to each other. Teachers have an important role in the classroom, because they are keys who lead the students. The students imitate their behavior and quote their statements. All of these occur in the classroom.

Furthermore, language learning process is a very complex problem. No one knows exactly how people learn languages because it is an internal process. The internal learning process that is experienced by a student cannot be directly observed. So that, a teacher 
should pay attention to any indicator that reflects the learning process experienced by her or his students.

Moreover, in English language teaching and learning situation, this internal process experienced by the students is often hampered by lack of supporting factors. One of the main factors influencing the success of students in language learning circumstance is the teachers' approaches.

Many education studies have investigated learning strategies since the 1980's, and this has also been a trend in second and foreign language education. Researchers have discovered that successful L2 learners, compared with their less successful classmates, used more strategic mental processes (learning strategies) and employed them more frequently; this strategy use was shown to occur before, during, and after L2 tasks

In Bloom revised taxonomy, fundamental teaching consists of material, media, process and evaluation (Killen, 2005). The teaching process consists of teacher, learner, material, and context. As a matter of fact, materials, teaching methods, and evaluation should all be designed for learners and their needs. It is the teacher's responsibility to check to see whether all of the elements of fundamental teaching suitable for learners and to adapt them if they are not. Therefore, this fundamental teaching must be judgments in organizing English teaching at elementary school.

The proliferation of approaches and methods is a prominent characteristic of contemporary second and foreign language teaching invention of new classroom practices and approaches to designing language programs and materials reflect a commitment to finding more efficient and more effective ways of teaching languages (Richards, 1995:vii).

The classroom teacher and the program coordinator have a wider variety of methodological options to choose methods and materials according to the needs of learners, the preferences of teachers, and the constraints of the school or educational setting.

In the century spanning the mid-1880s to the mid-1980s, the language teaching profession was involved in what many pedagogical experts would call a search. That search was for a single, ideal method, generalizable across widely varying audiences that would successfully teach students a foreign language in the classroom. Historical accounts of the profession tend, therefore, to describe a succession of methods, each of which is more or less discarded in due course as a new method takes its place. (Brown, 2008:9)

Learners in indonesia, eventhough have studied English from elementary school up to university, there are still little of them can master English well. Asfah Rahman (2005) points out that students' ability in English is still low. It was indicated by the following: (1) the new students' mastery of the 1994 curricular objectives is $45.31 \%$, (2) their mastery of English vocabulary is $40.15 \%$ or at the low level, and (3) their mastery of English grammar is also low. 
Students' low ability can be caused by student's classrooms' culture' that is not conducive to the learning process. In the classroom, students are supposed to sit nicely, listen to the teacher attentively and are obedient to him. The teacher is the only one who is supposed to know everything and therefore becomes the one who dominates the classroom.

Furthermore, there are three of the English language learning classroom's most critical problems with comments on what might be done in dealing or managing each one. They are lack of learner motivation, insufficient Time, Resources and Materials, and overCrowded English Classes (Linch, 2011).

There are three key principles that help students to learn new language easily and effectively. As people, we like to simplify things. The simpler they are, the easier it is to get our heads around the core concepts that can affect us. In language learning, these three key principles will drill all the work involved into a neat and tight package. The three key principles are exposure, practice, and get to know the People.

Based on the principle, it indicated that the native teacher will facilitate students more exposure and more practice in learning. Native speaker teachers can make it easier to learn and understand the English language. Native speaker teachers will have the experience of speaking the language and have a better and less complicated way of providing explanations. When implemented correctly, teaching English to foreign students can be rewarding and enjoyable for both the teacher and the students.

International Class Program (ICP), Faculty of Mathematics and Science, State University of Makassar implements an undergraduate program. The graduates will get title from State University of Makassar if they have fulfilled all requirements as like as the regular program have implemented. The designation after completing the education program in ICP is similar with the designation of regular program at State University of Makassar. Undergraduate program of ICP FMIPA UNM employs undergraduate education in some fields: Mathematics education; Biology education; Chemistry education; Physics education, and geography class. Curriculum of ICP FMIPA UNM is ICT based. Responsibilty study of Bilingual student is 144-146 credits with the period for 10 semester or less than 10 semester or maximum 14 semester. Pre words in lecturing use Englisl ' $\cdots$, and bahasa Indonesia40\% (http://icp-fmipa. unm. ac.id/ v2 /index.php/profil)

Based on the reason, the researcher is interested to investigate "The Native Speaker's Methods in Teaching English for Indonesian".

\section{B. REVIEW OF RELATED LITERATURE}

This part deals with the previous related studies, some pertinent ideas, and conceptual framework. 
Nutt (2011) points out that native speaker can make easier to learn and understand the English language. Understanding English slang, and how native English speakers engage in conversation is something that cannot be learned in a text book. Although there can be miscommunication regarding culture and customs, native speaker teachers can make easier to learn and understand the English language. Native speaker teachers will have the experience of speaking the language and have a better and less complicated way of providing explanations. When implemented correctly, teaching English to foreign students can be rewarding and enjoyable for both the teacher and the students.

Chomsky in Andreou (2009) claims that native speaker is the ideal informant regarding grammatical judgments. Therefore, a native speaker is the authority on the language, the only one, who can characterize sentences in grammatical terms.

Therefore, it indicated that the native speaker, can make students easier to learn and understand the English language because they are the ideal informant regarding their own Language. In this point, the researcher would like to investigate the methods used by native speaker in teaching English for Indonesian students in Makassar.

Edward Anthony (Richard, 2009:19) gives us a definition that has quite admirably withstood the test of time. His concept of method was the second of three hierarchical elements, namely, approach, method, and technique. An approach, according to Anthony, was a set of assumptions dealing with the nature of language, learning, and teaching. Method was defined as an overall plan for systematic presentation of language based on selected approach. It followed that techniques were specific classroom activities consistent with a method, and therefore in harmony with an approach as well.

On the contrary Richard points out that method was an umbrella term to capture redefined approaches, design, and procedures. Similarly, Prabhu thought of method as both classroom activities and the theory that informs them. For most researchers and practicing teachers, a method is a set of theoretically unified classroom techniques thought to be generalizable across a wide variety of context and audiences (Brown, 2008:9).

Diane Larsen (2003) points out eight methods in language learning, namely the grammar translation method, the direct method, the Audio-lingual method, the silent way, suggestopedia (desuggestopedia), community language learning, the total physical Response, and the communicative approach, content based, task based, and participatory approaches, learning strategy training, cooperative learning, and multiple intelligences.

In addition, Richards (2001:5) puts out some examples of approaches in language learning, such as communicative language teaching, competency based language teaching, content based instruction, cooperative leaning lexical approaches, multiple intelligences, the natural approaches, neurolinguistics programming, task-based language teaching, and whole language. They also give examples of methods such as audiolingualism, counseling learning, situational language teaching, the silent way, suggestopedia, and total physical response. 


\section{METHOD OF THE RESEARCH}

This reasearch employed a qualitative reasearch design. The qualitative research approach applied here was the case study approach. The type of case study was used in this research is ethnographic which was carried out in-depth investigation of methods used by native speaker in teaching students at ICP UNM and students' involvement during the classroom process. Gay et.al (2006:402) stated that the case study approach, as a type of ethnographic research design, focuses on the exploration of phenomenon that occurs within a bounded system. He also suggested that an ethnographic case study focuses on describing the activities of a specific group and the shared patterns of behaviour it develops over time (Gay et.al, 2006:445). Stake (2000:437) stated that the study of case is chosen because it is believed that understanding it will lead to better understand, perhaps better theorizing, about a case. Yin in green et.al. (2006:112) stated that the case study method is best applied when research addresses descriptive or explanatory questions and aims to produce a first hand understanding of people and events.

The informant of the research was the native speaker who teaches English to Indonesian students at ICP (International Classroom Program) State University of Makassar. The students of ICP (International Classroom Program) were chosen because the class was taught by native speaker. The native speaker is Shane Perryman.

The researcher employed some instruments to facilitate this research. The first one was collect data of observation and interviews. The other helpful instruments were (1) a journal to make field notes and interview transcripts, (2) a recorder to record the interview, and (3) a video camera to support the field observation and take photographs.

The data collection took in the school particularly in the ICP classroom. The native speaker and the students were studied in their own classroom and other places. A study case as one of the qualitative research approaches relied heavily on the observations, interview, phone calls, photographs, recording and informal conversations. The researcher mainly applied interview, direct observation, taking photographs, and making phone calls. Here, the researcher mostly became a passive participant observer that assumues no responsibilities in the classroom settings but only focuses on the data collection.

After collecting the data from the observation, and interviews, the researcher analyzed it using the grounded theory data analysis technique. The researcher fully examined each piece of information and building upon those insights and bunches gained during the data collection.

There are three types or stages of data analysis in the grounded theory method. These stages are called open coding, axial coding, and selective coding (John and Christensen:381)

1. Open coding is the first stage in grounded theory data analysis. It begins after some initial data have been collected, and it involves examining the data (usually reading 
transcripts line by line) and naming and categorizing discrete elements in the data. In other words, it involves labeling important words and phrases in the transcribed data.

2. Axial coding follows open coding. During axial coding, the researcher develops the concepts into categories and organized the categories. The researcher then looks to see what kind of things the participants mentioned many times. The researcher also looks for possible relationships among the categories in the data. A goal is to show how the phenomenon operates.

3. Selective coding is the stage of data analysis in which the researcher puts the finishing touches on grounded theory for the current reserch study. In particular, this is where the grounded theorist looks for the story line of the theory (i.e., the main idea) by reflecting on the data and results that were produced during open coding and axial coding. The researcher will usually need to continue to analyze the data, but with more focus on the central idea of the developing theory. Ultimately, it is during selective coding that researcher writes the story, explaining the grounded theory.

Doing the selective coding, the researcher also triangulated the data from interview, observations, and photographs to provide a more valid data and result. Burke 92004:424) said that triangulation is a term given when the researcher seeks converge and corroboration results from different methods studying the same phenomenon. Gay, at al. (2006:446) stated that triangulation is the use of multiple methods, data collection strategies and data sources to get more complete picture of what is being studied and to cross check information. Finally, the researcher interpreted the data and presented it as the result of this research.

\section{FINDING AND DISCUSSION}

\section{The profile of Informant}

The informant is Shane E. Perryman (44 years old). His last education is $\mathrm{PhD}$ at Monash University (Melbourne), School of chemistry, water study center and also at the Murray Darling Freshwater research centre. His career focus is the concequence of human activities on the cycling of nutrient and element in the environment, and the flow on effect this has on the biodiversity and function of ecosystems. He is not a language teacher as he explained in interview:

"ok so if... I am not a language teacher my teaching in Australia has been in University to chemistry student. Am... the education system must be different. University in Australia by the times student get to the university in Australia at least when I was teaching. The student, understand that they are expected to take more responsibility for the learning. Where here in Indonesia I getting impression that I let you to tell the student exactly what to do and they don't take the initiatives as much. So if I take do this task and I want to do this.. this and in Indonesia I find that I have 
to go I want to do this and I want to do it this way, I want to do this and I have to done this way" (FN 09).

Based on the extract at line 1 and 2, the informant said that he is not a language teacher, but he has experience in teaching. He does not also have background education in language learning. He has taught English at UNM for about 2 years.

He is assigned to teach english at International class program, the kind of english as a specific purposes (ESP) especially Englisg for academic Purposes. His position as a practioner.

\section{Teaching procedures}

a. Observation 1

The material of the teaching in first observation (appendix 2) is The Microbes May Make Us Fat-Student. The observation was conducted on 27 $7^{\text {th }}$ September 2011 and done for 90 minutes as can be seen in FN 002.

Firstly, the lecturer opened the lecture by greeting students and did the aperception. Lecturer asked students about the material that had been given in the previous week. After that the lecturer introduced the material of the meeting and gave instruction what they should do in the meeting. Then the lecturer distributed the task to the students and explained what should be done to the task (see FN 002).

After that the lecturer turned on the listening material, while the students did the task. The task is filling gap (Appendix 3), so students during the listening process, they should fill in the gap. The material turned once, so that the lecturer asked students to listen carefully (see FN 002).

The lecturer focus the subject on this session on listening. Based on the interview, lecturer focus on vocabulary, reading, listening, and speaking. It is caused by the students need to communicate in English. This can be seen in the following extract:

"What I'm going trying to do is I don't focus on grammar ok. I can't teach my student on grammar lesson because it was not my area to taught. I don't know the name how the different grammar. I know many but I don't know I'm not too and I don't think it's not necessarily important for them to be able to speak for communicate. Junior high school they have taken that grammar lesson and focus on grammar. What they need now is I think more vocabulary, practice speaking, and practice listening so in my classes I'm trying to facilitate here and I'm trying $<$ missing $>$ if contain words, that unique to know because that the word, most of people in the population in Australia would know or could get. Amm..you should practice speaking in the <missing $>$ I would ask question, role play, introduce and then the other time I will give them the radio show and then ask them did you understand, ask them question or I give them the test < missing > " (FN 09). 
Based on the extract, it informs that the lecturer did not teach grammar because it was not his area. He also added that it's not necessarily important for them to be able to speak for communicate and actually the students had got grammar on junior and senior high school. According to him what the students need now are more vocabulary, practicing speaking, and practicing listening. In order the students can practice speaking, he facilitated students the material and activity that can support the goal.

After that the lecturer explained generally the material the students and then discussing the task. The lecturer used body language, picture, and gesture to explain the meaning of the difficult words or new words (see FN 002).

Next, the lecturer play the listening material again and giving the transcription to the students. In this section students asked to listen in order that the students can know the correct pronunciation of the words (see FN 002).

Before the lecturer closed the lecture, he motivated students to learn hard and asked students to learn more about the task in their house because he would get them the test for the next meeting (see FN 002).

b. Observation 2

The material of the teaching in first observation (appendix 5) is Fat-busting bacteria not a hard act to swallow. The observation was conducted on $28^{\text {th }}$ September 2011 and done for 90 minutes (see FN 003).

Firstly, the lecturer opened the lecture by greeting students and did the aperception. Lecturer asked students about the material that the lecturer had given the previous week. After that the lecturer introduced the material of the meeting and gave instruction what they should do in the meeting (see FN 003).

Then the lecturer distributed the task to the students and explained what should be done to the task. The lecturer should try hard to explain the instruction to the students in order that students can undstand well. In explaining the instruction, the lecturer used body language.

After that the lecturer turned on the listening material, while the students did the task. The task is filling gap (Appendix 6), so students during the listening process, they should fill in the gap. The material turned once, so that the lecturer asked students to listen carefully. After radio show turned off, the lecturer gave fife minutes to compelete the task and then the lecturer collect the task.

After that the lecturer explained generally the material to the students using LCD. The lecturer showed the material and explained the material in English. He used body language to help him make students understand the meaning of the words. In this seccion, the activity started with listening and continued by reading the material. He explained words per words. Then students were given chancs to ask question. The students then asked question and the lecturer answered the student question. The focus of the lecturer 
this meeting as the same with the first observation to improve vocabularies and learn about the correct pronounciation of words.

Before the lecturer closed the lecture, he showed the film to the students about how to fish and then explained to the student the situation at the film. He motivated students to learn hard and asked students to learn more about the task in their house because he will get them the test for the next meeting.

\section{c. Observation 3}

The material of the teaching in third observation is Territorial. The observation was conducted on $29^{\text {th }}$ September 2011 and done for 90 minutes (see FN 004).

Firstly, the lecturer opened the lecture by greeting students and did the aperception. Lecturer asked students about the material that the lecturer had given the previous week. After that the lecturer took register and then introduced the material of the meeting and gave instruction what they should do in the meeting. Before starting the lecture, the lecturer gave emphasis to student's vocabulary.

Next lecturer divided students into group of five members. Then the lecturer distributed the task to the students and explained what should be done to the task. And then students did the task for about 20 minutes. The objective of the task is to translate sentences. Each group was given a piece of paper containing sentences that must be translated into English or into Indonesian. After that students were asked to arrange the sentences into good paragraph (see FN 004).

The above figure shows that students work in group. In this activity, students translate the sentences given by the teacher and then arranging into good paragraph. In this activity, the lecturer came to each group to guide them. Sometimes he helped students by writing the difficult words that make students confused when the lecturer informed a word or sentences. After the students did the instruction, they must read that work in front of the class.

After all the groups did that, Mr. Perryman gave games to his students. He did throw the ball to his students and the students must answer the question. It is just about the similarity of the words. He takes that question based on the materials. The students felt excited (see FN 004).

Before the lecturer closed the lecture, he summed up the lecture and motivated students to study hard and asked students to learn more about the task in their house.

\section{d. Observation 4, 5, and 6 (The Same Material in Different Class)}

The material of the teaching in third observation is natural disaster, earthquake, Tsunami, landslides, poisonous mud, Death Toll, and missing adam air. The observation was conducted on $4^{\text {th }}$ November 2011 and done for 90 minutes at chemist class, on $5^{\text {th }}$ November 2011 at math class, and on $6^{\text {th }}$ November 2011 geography class. 
At chemist classroom program, He started the class by greeting student then giving warming up based on previous meetings. He asked the students to open their material that taken from www.unm-icp.blagspot.com. He put all material there for his students so the students felt easier to get his material and had a time to learn more about his material before he came to the class. After that the lecturer introduced the material of the meeting and gave instruction what they should do in the meeting as can be seen in the extract as follows

Lecturer: good morning everybody, as I hope you all gain this, yess, read first, @how ways@, yess.. Last week I gave you gap filling lecture, so that ee that this week I emphasize lecture to everybody. As I recognized, everybody is reached do the same thing... What we are going to do today is, while I got you to do the task.. there was some exercises.. some knowledge did you to read... in class today we just to try on to.. to this story.. read through them.. if you cannot understand the clear pronunciation.. I guide first, explain some words.. making interesting story to show you perhaps how you can remember word. as I talking to you last week, that, you have making interesting story making, exiting person emotion, so that you can remember word, increasing vocabulary. the story is about disaster, earthquake, tsunami. another one is landslides, poisonous mud, missing adam air.

... The second one what you would you to do is. in pairs, in pairs, is you ask question about the stories.. if you are not confident, you can read, but I want you to try and do pre train. you are a journalist, you are instructor.. you have to ask what is happen, making it interesting, you ask about your family, how do you survive. if you have a bit little time to practice questions well, the types of the question can be used is what, where, when, how, and why

Then the lecturer read the reading material and tried to explained the meaning of the words by gesture and described the unfamiliar words through drawing. This section done for about 30 minutes.

Based on the extract, it informs the lecturer' talk in startiing the class. After gretting the students, the lecturer asked students whether they have gained and read the material before coming to the class as instruction given in the previous lecture (as I bope@you all gain this, yess, read first, line 1). Then the lecturer repeated to explain the activity in the previous meeting (line 2-4), continued to explain the activity that would run (line $4-20$ ).

Next, the extlecturer asked students to work in pairs to practice asking and answer questions about the stories. Students do the role play one as a journalist and another students as interactor (FN 005) 
The figure shows that teacher guided students to do the activity has been explained. The lecturer explained the students to use the vocabularies in reading material to construct their own pair work conversation.

Next, students work in pairs, and lecturer come to each pair to guide them to do the task.

Finally, the lecturer gave reinforcement to the students about the speaking practices that the students do. The lecturer reminded students to practice asking question. Then the lecturer gave task to do the students for next week.

The difference between the third and the fifth activity is on the student's participation. The geography students looked more active to speak rather than chemist and math class (FN 007).

He explained that words based on their program. He tried to found the easier words to explained to his students at the time. He looks professional when he did that to his students, most of the student understood what the lecturer said because Mr. Perryman really understood what his students' needs and want to learn. He tried become familiar to his students by understanding them and share with them in the closing class. He opened students's mind, so the students felt comfortable in his class. The students said to us at the timeL: "We felt comfortable and never felt afraid to speaking English in his class because he never get angry to us. He teach us very patient $\mathrm{c}$ he always tried to understend us, sometimes we make him angry but he doesn't angry at all he just lough and smile to us".

At mathemathic class program, He explained the material focus on the numeral. How much the victim from disaster. So the lecturer explained material based on the math class need (FN 006). And at the geography class, he relateted the main material with material related to geography for instance the structure of universe (FN 007). Therefore, it fulfiils students' need.

\section{e. Observation 7}

The material of the teaching in third observation is natural disaster, earthquake, Tsunami, landslides, poisonous mud, Death Toll, and missing adam air. The observation was conducted on $11^{\text {th }}$ October 2011 and done for 90 minutes. The observation in chmestry class. (see FN 008)

Firstly, the lecturer opened the lecturer by greeting students and did the aperception. Lecturer asked students about the material that the lecturer had given the previous week. After that the lecturer introduced the material of the meeting and gave instruction what they should do in the meeting. Firstly, the lecturer gave test related to the previous lecturer. The test (appendix 13) is complete test (complete the missing word in paragraph and complete the table). (See FN 008) 
After students did the test, the lecturer together the students discussed the test. After that the lecturer ask students to practice speaking through pair works as having pre train the previous week. Each pair must perform the pair work task.

The above figure is students' activity in pair work. In this activity students asked to practice speaking.

While the students were presenting their conversation in front of the class, the lecturer tried to found the words errors in their speaking. After they did that conversation, the lecturer correct that words into the right pronunciation and into the right words.

Finally, before closing the lecture, He gave ice breaking to the student related to his story about his travelling around the world. His experience is talking about his tour in Europe with his family at that time. Through this activity the lecturer tried to motivate students and facilitate students with the interesting story.

\section{E. CONCLUSION AND SUGGESTION}

In relation to the research findings and discussion in the previous chapter, the conclusion is The procedures of teaching applied by native speaker in teaching English to Indonesian students at ICP UNM are the procedure required by direct method, ausdion lingual mehod, and communicative language teaching. Besides, the lecturer varied activities in each meeting through some kind of activities. The lecturer also always applied two main activities in each meeting. The lecturer applied tutorial, pair work, and role play.

Based on the result of the data analysis and the conclusion above, the researcher presents the following suggestions:

1. Teachers should formulate the goal of the lecturer based on the students's need and the theory of language learning in order that the students can learn the language easily.

2. Teacher in classroom activity should also play role not only as a teacher but also as facilitator, manager, director, guide, educator, and motivator.

3. Some activities used by the native speaker are expected to be references for the Indonesian teachers to be applied in classroom activity in order to increase 3 student's participation.

4. In order that students can get more chances to practice English and they can be encouraged to learn English, teachers should apply the teaching procedures applied by the native speaker, the teacher can also modify based on the students' need and classroom condition.

\section{REFERENCES}


Nurfajri Ningsih, Native Speaker in Teaching English to Indonesian ...

Diane Larsen-Freeman. 2003. Techniques and Principles in Language Teaching. USA. Oxford University Press.

Georgi Lozanov. Suggestopedia. Learning is a matter of attitude, not aptitude. Online. http://www.jwelford.demon.co.uk/brainwaremap/suggest.html. Accessed March 292011

Gay, L. R. 2006. Educational Research: Competencies for Analysis and Application. United State of America: Prentice-Hall, Inc.

Jack C. Richards, and Theodore S. Rodgers. 2001. Approach and Methods in Language Teaching. USA. Second Edition. Cambridge University.

Jack C. Richards, and Willy A. Renandya. 2002. Methodology in Language Teacbing. America. Cambridge University Press.

Louis Cohen, et al. 2007. Research Method in Education. Newyork: Routledge.

Muhammad Basri Wello, and Hafsah Amien. J. Nur. 1999. English for Specific Purposes. Makassar. Badan Penerbit UNM.

EFL Teaching Method. Online. http://teflbootcamp.com/teaching-skills/teachingmethods-for-tefl/. Accessed March 212011.

Methods of Teaching Foreign Languages. Online. http://en.wikipedia.org/wiki/Methods_of_teaching_foreign_languages. Accessed March 262011.

Methodolgy, Approach, \& Method Definition in English Language Teaching. Online. http://www.shvoong.com/ humanities/ linguistics/ 2032735-methodolgy-approachmethod-definition-english/.Accessed March 262011.

A Grammar-Translation Method. Online. http://eng.hi138.com/?i50723. Accessed March 292011.

Audiou-Lingual Method. Online. http://en.wikipedia.org/wiki/Audiolingual_method. Accessed March 292011.

Proprioceptive language learning method. Online. http://en.wikipedia.org/ wiki/Proprioceptive_language_learning_method. Accessed March 292011.

Suggestopedia. Online. http://en.wikipedia.org/wiki/Suggestopedia. Accessed March 292011.

Richards, J. C,. and Rodgers, 1995. Approaches and Methods in Language Teaching. Cambridge University Press.

Tracy Terrell and Stephen Krashen. 1977. The Natural Approach. Online. http://www.sil.org/lingualinks/languagelearning/waystoapproachlanguagelearning/th enaturalapproach.htm. Accessed March 292011

Yin, Robert K. (2003). Case Study Research: Design and Methods. Thousand Oakds: Sage Publications. 